\title{
Information and image support of the activities of the Agrarian University
}

\author{
Marina Alemasova ${ }^{1, *}$, Dmitry Galkin ${ }^{1}$, Ludmila Kurbatova $^{2},{\text { Zhoia } \text { Olovyanikova }^{3} \text { and }}^{2}$ \\ Svetlana Popova ${ }^{1}$ \\ ${ }^{1}$ Michurinsk State Agrarian University, Internationalnaya St., 101, 393760 Michurinsk, Russia \\ ${ }^{2}$ Perm National Research Polytechnic University, Akademika Koroleva Street, 15, Perm, Russia \\ ${ }^{3}$ Pskov State University, Lenin Square, 2, Pskov, Russia
}

\begin{abstract}
The article examines the activities of public relations specialists of Michurinsk State Agrarian University in its information and image support. The paper analyzes communication technologies aimed at promoting the higher educational institution of an agrarian profile, agricultural education and agrarian science in general. It is argued that the formation of a positive image of Michurinsk State Agrarian University is facilitated by the organization of effective interaction with the media, positioning of the activities of the university, its scientists, students; regular media monitoring; formation and strengthening of corporate culture; development of corporate identity, mission, slogan, logo; organizing and holding special events; preparation and participation in exhibitions and fairs; maintaining a corporate website; production of a corporate publication, advertising activities. Specific examples of the use of communication technologies in an educational institution are given. The conclusion is made that with the creation of a department for public relations and management of public relations, press and office work, the communicative activity of the agrarian university began to be carried out professionally and in a coordinated manner. The existing communication system ensures the formation of an effective positive information field of the university. The communicative policy of the educational institution is focused on the long-term prospect of building a serious positive dialogue with target audiences, on the prospect of trust.
\end{abstract}

\section{Introduction}

Nowadays, managing your own information flows becomes a necessity for any organization that wants to function in society for a long time and effectively. The higher education system is no exception. In conditions of intense competition "universities have to look for and find non-trivial ways to attract a future contingent of students" [1,83]. Without the efforts of advertising and public relations specialists with the necessary set of knowledge and personal qualities, including creativity, courage, initiative, resistance to stress [2-3] the successful implementation of this task is not possible.

\footnotetext{
*Corresponding author:mal_2112@mail.ru
} 


\section{Materials and Methods}

When writing this article, we used works devoted to the peculiarities of advertising and PRactivities in a higher educational institution; annual reports of the department of public relations and department of public relations, press and office work of Michurinsk State Agrarian University; publications and broadcasts in the media (newspapers, magazines, almanacs, radio, television) about events, projects, discoveries of university scientists; souvenir and advertising products. Methods of observation, analysis and description were used.

\section{Results and Discussion}

One of the main tasks of public relations in a higher education institution is to form a positive public opinion about the institution; control of the information field around the positioning object. For the effective promotion of agrarian universities, agricultural education and agrarian science in general, various communication technologies are used, combined into a system of thought-out strategically built actions.

PR activities have been carried out since 2004 in Michurinsk State Agrarian University. First, the position of a public relations specialist was introduced and then a PR department was formed with the aim of activating and increasing the effectiveness of work in the field of positioning the agricultural university in the external environment, expanding the scale of work to popularize agricultural education. Currently, there is a public relations department, the purpose of which is to provide information and image support for the university's activities or, using the language of professional terms, to increase the publicity capital of the basic subject of PR [4].

The department interacts with all structures of the university; mass media (newspapers, television, radio stations and Internet news portals) and information agencies, press services and public relations departments of the city of Michurinsk-Science City of the Russian Federation, the administration of the Tambov region and agrarian universities of the country.

A key area of public relations activities is the organization of interaction with the media - media relations. PR specialists build trusting positive relationships with journalists of newspapers, magazines, radio, television serving as a base and resource for the use of other communication technologies. Constant work with the press, includes the distribution of press releases, the publication of image articles about the personalities of the university, the holding of special events for the press (briefings, press conferences). Preparation of answers to their official inquiries contributes to the formation of a positive image of the university [5].

In the process of carrying out public relations activities at the university, fruitful cooperation has been established with the mass media of the city, region and country. Thanks to the comprehensive and regular coverage of the life of the university in the media, public confidence in the university has increased; the activities of Michurinsk State Agrarian University have become transparent in the training of personnel and the implementation of research activities for the domestic agricultural industry. In the press and on the radio there are constant headings "News of Michurinsk SAU". Journalists of "Tochka", "Vesti Tambov" and "Novy Vek" TV companies regularly cover the activities of the university in their news and feature stories which are initiated by PR specialists. The materials are mainly devoted to the scientific and innovative activities of the university, the discoveries and inventions of Michurinsk scientists, which contribute to the formation of an attractive image of agricultural science. News materials are also being prepared for the website of the Ministry of Agriculture of the Russian Federation. 
Management specialists actively cooperate and regularly interact with the editors of professional journals, on the pages of which materials about the university and its scientific developments are published. These are the almanac "Universities of Russia", the magazines "Adviser in the field of education", "Adviser to the accountant", "Education: goals and prospects", etc.

In the summer of 2021 Michurinsk was visited by representatives of the Federation Council TV channel "TOGETHER - RF", who filmed for the cycle of programs "Science Cities". This program is about the past, present and future of Russian cities and towns with high scientific and technical potential. A big story about the only agricultural science city and towns in Russia was broadcast on TV, and a separate part of it was devoted to Michurinsk State Agrarian University (from 19 minutes) [6].

Since PR-activity is informational, the indicator of its effectiveness is the number of prepared information products, the number of addressees who received information products and the number of changes that occurred as a result of receiving information products [7]. According to these criteria, the information support of the activities of Michurinsk State Agricultural University is carried out competently and fruitfully.

During a difficult situation for the university related to the integration of educational institutions of Michurinsk on the basis of Michurinsk State Agrarian University a lot of information materials were published highlighting the need and the process of combining four higher educational institutions and colleges which made it possible to correctly adjust the public to this process and not cause resonant sentiments.

The university also publishes its own corporate publication "The Bulletin of Michurinsk State Agrarian University", the editor-in-chief of which is the head of the public relations department. The professional management of the newspaper contributed to its dramatic change. It has become more interesting and modern by changing its content and using full color printing in the production of mass printed product.

One of the most important components of the communication system of an educational institution is the formation and strengthening of corporate culture. It unites teachers, employees, students of the university into a team of like-minded people for the effective implementation of its mission, which was developed with the active participation of public relations specialists. Corporate culture defines the strategic goals of the educational institution. The text of the mission is aimed at both teachers and staff of the agrarian university and its students. Its main provisions determine the principles of educational, scientific activities; emphasize the university's focus on spiritual and moral education of the personality of students, the disclosure of the creative abilities of employees and students, the desire of the university to integrate into the international educational space.

The most important component of corporate culture is the corporate identity - a set of graphic forms and principles of building visual communication, united by one idea, the main task of which is to highlight the organization and create a recognizable image in the eyes of target audiences: teachers, employees, students, applicants, employers, partners, authorities, media representatives. Corporate identity includes a name, a coat of arms, an anthem, a flag, a uniform, a logo, a slogan.

The corporate identity of the Michurinsk State Agrarian University, which was developed by the university's PR specialists, is made taking into account the specifics of the organization, the agrarian profile of many specialties. Green and white were chosen as corporate colours. Green is a symbol of unity with nature, white is a sign of purity and harmony.

The university logo is an apple framed in a semicircle with a stylized map of the Russian Federation inside. Since ancient times the circle has been considered a sign of unity and perfection. Apple orchards are a "visiting card" of Michurinsk. Apple varieties bred by I.V. Michurin and his followers including scientists from Michurinsk State Agrarian 
University are known throughout Russia, which is demonstrated by the map inside the apple (fig. 1).

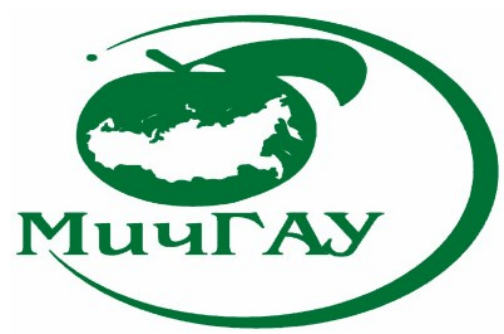

Fig 1. The university logo

Each institution of the university has its own logo that reflects the specifics of its activities. Despite the characteristic differences, they all contain unifying elements, which are ears of wheat (a sign of wealth), a master's hat and an open book (symbols of knowledge).

The university created and patented the brand name of university eco-products "101 VITAMIN".

Corporate symbols on the clothes of representatives of the youth movements of the educational institution began to distinguish the students of the agrarian university of the Tambov region from others during mass events.

The slogan of Michurinsk State Agrarian University is "Together - to success". The phrase is laconic, easy to remember. It is featured on all advertising and souvenir products produced by the university.

Michurinsk State Agrarian University has its own anthem (words by V.N.Zmeevsky, music by N.P. Ermilova -teachers of the university), the performance of which opens all official events held at the university. The flag consists of two horizontal stripes: white and green. At the top of the flag there is a logo with the full name of the university. When designing business letters and various documents, the university uses the proprietary font "Bangkok Cyr". Elements of branding are used in the design of corporate publications, the official website, souvenir and printing products, outdoor advertising and exhibition stands.

Organization and holding of special events is a significant component of the university's communication policy and a tool for strengthening its corporate culture. Various events are regularly held: concert programs dedicated to calendar holidays, anniversaries in the history of the university; contests and sports competitions in which students, teachers and university employees participate. For the student audience are organized competitive programs "Student Spring", "Freshman's Debut", "Student Family", "Mister and Miss of Michurinsk SAU", "Best Leader of Michurinsk SAU ". They "are designed to bring variety and revitalization into the daily work of the team, contribute to the formation and strengthening of a positive image of the university" [8, 5].

The competition "Mister of Michurinsk SAU", invented by students of PR specialists, is a kind of meeting "without ties "for the leadership of the university. The organizers managed to go beyond the standard perception of the leadership, to show in an unusual perspective those who are more often used to see in situations of strict officialdom, to "bring them closer" to students, teachers, and employees. Representatives of the administration recalled their student years, told funny stories that happened to them, peeled potatoes, demonstrated the ability to replace, if necessary, a spouse in the kitchen, made solemn speeches in honor of their wives, and performed lyric songs. The rector and his team were assessed by a student jury, very loyal to all the participants, apparently counting on a similar attitude towards themselves in the future. The competition revealed unexpected, previously unknown to the majority of those present, talent of the university 
administration, helped to raise the level of awareness of each participant as a person. Such contests, in addition to a good mood and sincere fun, set the stability of the moral and psychological climate of the team, help support the activities of the management, and form a single corporate spirit $[8,6]$.

Exhibition activities have become a widespread means of promoting the university. Participation in exhibitions and fairs supports the image of the educational institution both in the eyes of wide public groups and target audiences. The exhibition allows attracting the attention of potential applicants and employers to the activities of the university. Thanks to the PR-specialists of the university, the direction related to exhibition activities has reached a new level. Participating in major events of the all-Russian level ("Golden Autumn", "Russia, Looking to the Future!" , "Gardener's Day"), Michurinsk State Agrarian University positions itself as a higher educational institution of an agro-social profile, implementing training directions for the integrated development of rural areas.

The beginning of the second decade of the new millennium has finally confirmed the importance of the global information environment in society. The World Wide Web has created a new - informational - paradigm that promotes the availability of information, its mobility and lack of attachment to certain time parameters.

The Internet has become a part of the life of every citizen of Russia: people work there, communicate, and arrange their personal life. People are spending more and more time online. This is also related to the aspiration of domestic organizations to the Runet sphere. Michurinsk State Agrarian University is no exception [9, 141].

The representation of an educational institution on the Internet is an essential element of communication.

"The news feed of the site of Michurinsk State Agrarian University is popular and is included in the list of topical news sources. More and more Internet resources refer to articles from www.mgau.ru/about/news/ "[9, 142].

Users receive information about the know-how in the educational institution; the system of continuous agribusiness education; find out for which developments young scientists receive millions of grants; why eighty-year-old applicants enter the university, what form fruits grow in the "Green Valley" of the university, how employees help to grow vegetables in the Far North.

The development of telecommunication and digital technologies, mobile devices, computer technology, the Internet creates the prerequisites for the use of digital-mail - a modern way to promote a brand. Considering that young people - applicants, students, graduates (key segments of the target audience of the university) - are most susceptible to the communicative impact of modern gadgets, the university widely uses direct-mail, forming and using personal electronic address databases for sending advertising and information messages university. Potential students can receive the necessary information promptly and directly.

Advertising technologies are used to position the activities of the university. Advertising is the most traditional channel of promotion, allowing applicants to be informed about the specialties and areas of training of the university. Advertising professionals use all types of traditional advertising. Advertising messages are published in print media, they sound on radio, television, they are present in brochures, reference books, calendars, postcards, leaflets, leaflets, booklets, memos. Outdoor advertising is placed on the facades of buildings, transport, pylons, and guy lines. The advertising carriers of Michurinsk SAU are billboards, posters, stickers, light boxes, banners. Particular attention is paid to the placement of advertising messages on the Internet - contextual advertising, flash banners, targeted advertising in social networks, etc.

Advertising of Michurinsk State Agrarian University changes conceptually every year. 
Developers of advertising messages always strive to get away from traditional ideas in the field of higher education, sometimes to combine the incompatible. For example, one advertising concept was based on the idea of speed. The emphasis was placed on the combination of the concepts of "speed" and "knowledge". The result is an original advertising phrase - "Education at Michurinsk SAU - at the ultimate speed of knowledge!" The billboard showed a speedometer (as if through a magnifying glass), its arrow went off scale for the last division of $160 \mathrm{~km} / \mathrm{h}$, an additional mark was placed behind it, but instead of a number there was a university logo: studying at the university will allow you to quickly move in step with the times with the acquired luggage of modern knowledge [10].

During the advertising campaign "Choosing Michurinsk SAU: Yesterday, Today, Tomorrow" two main ideas are combined: the theme of time, expressed in the categories of the past, present and future (yesterday, today, tomorrow) and the theme of choice. Key message: The right choice an applicant made yesterday is a happy student today and a successful graduate tomorrow. Key messages: choosing Michurinsk SAU for training, the students did not regret their decision: they found their favorite work here, opportunities for creative self-realization, found new friends; students of the agrarian university are confident in their future; the university today gives its students such knowledge that will help them achieve success tomorrow.

Another concept of the advertising campaign is based on the idea of the success and professional competence of university graduates.

Names and photographs were used in advertising materials, positions of forty-five wellknown specialists in the field of politics, culture, business, agriculture (heads of agricultural enterprises, heads of districts, rectors and directors of scientific research institutes), who at various times studied at Michurinsk SAU, were indicated. Promotional phrase: "Applicant! These people have achieved a lot by being educated at Michurinsk State Agrarian University! If you want to be successful go to Michurinsk SAU!" motivated potential applicants to study at the agrarian university. On the billboard and printed products in the center of the advertising material a free space was left for a photograph with the inscription "In 10 years your photograph will be here." The authors of the idea pursued the goal of encouraging applicants to present their photograph at this place and, accordingly, project it in the minds of themselves as a university graduate.

In the advertising campaign "Become Successful with Michurinsk SAU" the concept was implemented, according to which Michurinsk SAU was positioned as a university capable of giving its students the opportunity to achieve professional success and maximize self-realization. The key word "successful" focused on the following key messages: the university occupies a leading position in the region; it develops using innovative approaches to learning, strives to maintain and strengthen its leading position among the universities of the region; gives its students such knowledge that will help them to achieve success in the future.

University students (two girls and three boys) became the faces of the advertising campaign. The text of the commercial (audio and video) is "Success is always remembered! They trust him! He is always chosen because he makes others successful! Successful means the first! Successful means brave! Successful means the best! Get an education at Michurinsk SAU and become successful! Michurinsk Agrarian University - Together to Success! "

During advertising campaigns, advertising materials are produced: banners, posters for schools, brochures for applicants, video and audio clips, original layouts of publications in the newspapers "Moskovsky Komsomolets", "AIF-Tambov" and "Tambovskaya Zhizn", a banner for the official website university. Videos about the university are broadcast on the "Russia-2 TV channel" (Tambov), "STS", "TNT", "REN" and "Zvezda". The audio clips 
are broadcast on the radio channels "Hit FM", "Avtoradio-Michurinsk", "AvtoradioLipetsk", "Main Radio", "Russkoe Radio", "Road Radio - Tambov".

Advertising activity involves the production of souvenirs that are regularly updated at the university. It includes branded notebooks, key rings, pens, paper and plastic bags, chargers, badges, caps, T-shirts.

Thus, "Advertising provides information, informs / attracts attention, ensures the presence of the university in the advertising and information sphere. Today advertising technologies are a necessary resource and a means of ensuring the successful promotion of an educational institution" [11, 184].

\section{Conclusion}

Advertising and PR technologies are widely used by Michurinsk State Agrarian University to position its activities. Their complex use allows solving the problems of increasing the popularity of the university and strengthening its reputation, building the trust of target audiences, creating a positive information field. The communicative policy of the university is focused on the long-term prospect of building a serious confidential dialogue with target audiences.

With the introduction of the position of a PR specialist at Michurinsk State Agrarian University and later with the creation of a department for public relations and administration of public relations, press and office work, the communicative activity of the agrarian university began to be carried out professionally and in a coordinated manner. Relations have been established with the media and authorities. The work of the corporate website has been adjusted. High-quality advertising products are being produced.

\section{References}

1. E. Pervushina, Higher educ. in Russia, 11, 83-89 (2008)

2. Professional competencies of a communication specialist, ed. Krivonosov, 227 (2021)

3. L Semenova, A. Krivonosov, E. Karmalova, N. Danilova, Comprehensive program of professionally oriented training of specialists in communication, European Proceedings of Social and Behavioral Sciences, EpSBS, Grozny, Russia (2021)

4. E, Bykova, Medialinguistics in terms and concepts, 305-306 (2018)

5. I. Savelyeva, Modern media and the media market, 70-73 (2020)

6. Vmeste RF, https: //vmeste-rf.tv.

7. E. Bykova, D Gavra, Bulletin of St. Petersburg University. Language and Literature, 14-2, 275-284 (2017)

8. M. Alemasova, MediaVector, 1, 4-7 (2021)

9. D. Galkin, PR and advertising in a changing world: Regional aspect, 10, 141-144 (2012)

10. D. Galkin, Modern advertising technologies: theory and practice, $41-46$ (2012)

11. E. Malikova, Communication management problems: from theory to practice, 180184 (2013) 